\section{Implementasi Undang-Undang Nomor 5 Tahun 2014 Tentang Aparatur Sipil Negara (ASN) Terhadap Pelaksanaan Seleksi Pengisian Jabatan Pimpinan Tinggi Pratama di Lingkungan Pemerintah Provinsi Sumatera Utara}

oleh:

\author{
Ja'far Siddik
}

Abstrak

PengisianJPT baik di instansi pusat maupun daerah harus dilakukan secara terbuka untuk semua pegawai ASN yang memenuhi syaratsyarat jabatan dan standar kompetensi jabatan. Implementasi kebijakan pengisian JPT diwujudkan dengan terbitnya Peraturan Menteri Pendayagunaan Aparatur Negara dan Reformasi Birokrasi Nomor 13 Tahun 2014 tentang Tata Cara Pengisian JPT pada Instansi Pemerintah. Adapun permasalahan penelitian adalah Bagaimana pengaturan pelaksanaan seleksi pegawai Jabatan Pimpinan Tinggi Pratamadi Lingkungan Pemerintah Provinsi Sumatera Utara. Bagaimana implementasi Pengisian Jabatan Pimpinan Tinggi Pratama Menurut Undang-Undang Nomor 5 Tahun 2014 di Lingkungan Pemerintah Provinsi Sumatera Utara. Bagaimana factor penghambat dalam mengimplementasikan Undang-Undang Nomor 5 Tahun 2014 Terhadap Pelaksanaan Seleksi Pengisian Jabatan Pimpinan Tinggi Pratama diLingkungan Pemerintah Provinsi Sumatera Utara.

Penelitian bersifat deskriptif dan menggunakan pendekatan yuridis normatif dan yuridis empiris. Data diperoleh melalui penelitian kepustakaan(library research) dan penelitian lapangan(field research).

Berdasarkan hasil penelitian lapangan diperoleh pengaturan pengisian Jabatan Pejabat Tinggi Pratama oleh Undang-Undang Nomor 5 Tahun 2014 pada Pasal 108, Pasal 113 dan Pasal 115 dan Peraturan Menteri Pendayagunaan Aparatur Negara dan Reformasi Birokrasi
Republik Indonesia Nomor 13 Tahun 2014 tentang mekanis medan syarat-syarat yang harus dipenuhi oleh calon Jabatan Pimpinan Tinggi Pratama.

Kata Kunci :Implementasi, Aparatur Sipil Negara, Pengisian Jabatan Pimpinan Tinggi Pratama

\begin{abstract}
$P T$ filling in both the central and regional agencies must be carried out openly for all ASN employees who fulfill job requirements and job competency standards. The implementation of the JPT filling policy was realized by the issuance of the Minister of Administrative Reform and Bureaucratic Reform Regulation No. 13 of 2014 concerning Procedures for Filling in JPTs at Government Agencies. The problem of this thesis is how the arrangement of the implementation of the selection of high-ranking leadership employees in the North Sumatra Provincial Government. How is the implementation of the filling of the position of Primary High Leaders according to Law Number 5 of 2014 in the Government of North Sumatra Province. What are the inhibiting factors in implementing Law Number 5 of 2014 concerning the Implementation of the Charging Selection for the High Primary Leadership in the Government of North Sumatra Province.
\end{abstract}

The research is descriptive and uses a normative juridical approach and juridical empirise. Data obtained through library research (library research) and field research (field research).

Based on the results of field research, it was obtained the arrangement of filling in the position of Primary High Officials by Law Number 5 of 2014 on Article 108, Article 113 and Article 115 and Regulation of the Minister of Administrative Reform and Bureaucratic Reform of the Republic of Indonesia Number 13 of 2014 concerning the mechanisms and requirements must be fulfilled by the prospective Primary High Leadership Position.

Keywords: Implementation, State Civil Apparatus, Completion of Primary High Leadership Position 
Media Komunikasi dan Informasi Hukum dan Masyarakat

\section{PENDAHULUAN}

\section{A. Latar Belakang}

Aristoteles menyatakan manusia ditakdirkan sebagai makhluk sosial, atau yang dalam bahasa latinnya adalah "zoon politicon". Manusia tidak dapat dipikirkan sebagai makhluk yang hidup sama sekali terasing dan terpencil dari sesama manusia. Sebaliknya manusia harus selalu hidup dalam ikatan kelompok, ikatan golongan, ikatan kerukunan'. Manusia sebagai makhluk sosial dan sekaligus merupakan subjek hukumsaling berinteraksi untuk memenuhi kebutuhan hidupnya.

Interaksi minimal melibatkan dua pihak, dalam arti masing-masing pihak berkeinginan untuk memperoleh manfaat atau keuntungan. Hal ini menyebabkan kedua belah pihak menjadi saling terikat karenanya, dengan demikian yang dilakukan segenap kelompok sudah barang tentu adanya suatu ikatan-ikatan yang muncul memerlukan aturan. Sebab jika tidak ada aturan yang jelas, akan menimbulkan benturan kepentingan yang dapat mengakibatkan ketidakteraturan dalam kehidupan berkelompok ${ }^{2}$. Interaksi tersebut menimbulkan ikatan di antara mereka, jelas kegiatan ini bersifat privat. $^{3}$ Untuk itu hukum dibutuhkan untuk mengatur interaksi sesama manusia dalam kehidupan bermasyarakat

Dalam kajian ilmu hukum menurut isinya, hukum dapat dibagi menjadi hukum privat (hukum sipil) dan hukum publik (hukum

\footnotetext{
${ }^{1}$ Achmad Ihsan, Hukum Perdata

PT.Pembimbing Masa, Jakarta, 1967, h. 1

${ }^{2}$ Yahman, Karakteristik Wanprestasi \&

Tindak Pidana Penipuan yang lahir dari Hubungan Kontraktual, Prenadamedia Group, Jakarta 2014, h. 1

${ }^{3} \mathrm{M}$. Isnaeni, Makalah Disampaikan Dalam Pelatihan Hukum Perikatan Bagi Dosen Praktisi, Fakultas Hukum Universitas Airlangga Surabaya, 6 -7 September 2006, h. 3
}

negara) $)^{4}$. Hukum privat mengatur antara orang yang satu dengan orang yang lain, dengan menitikberatkan pada kepentingan perorangan ${ }^{5}$. Dalam arti luas, hukum privat meliputi hukum perdata dan hukum dagang, sedangkan dalam arti sempit, hukum privat hanya terdiri dari hukum perdata. ${ }^{6}$. Hukum publik adalah hukum yang mengatur hubungan antara negara dengan alat-alat perlengkapan atau hubungan antara negara dengan warganegaranya ${ }^{7}$.Adanya pembedaan hukum publik hukum dengan hukum privat menjadi permasalahan dalam praktek di pengadilan khususnya terkait dengan kebebasan sebagai hak asasi manusia.

Lamintang mensinyalir sering terjadi di kota-kota besar, di tempat yang sering diadakan perjanjian-perjanjian jual beli barang, perjanjian hutang piutang, dan lain-lain, dimana para penjual atau orang yang berpiutang sering kali datang kepada penyelidik atau penyidik melaporkan tentang dilakukan penggelapan melanggar Pasal 372 KUHPidana atau tentang dilakukannya suatu frelssentrekkerij melanggar Pasal 379a KUHPidana oleh seorang yang berutang, padahal maksud yang sebenarnya dari pelapor adalah agar orang yang dilaporkan itu kemudian mau membayar hutang-hutangnya setelah ia dimasukkan kedalam tahanan oleh penyidik. ${ }^{8}$

Hal senada Yahman menerangkan, tidak jarang dalam penyelesaian masalah yang berkaitan dengan ingkar janji, yang pada dasarnya merupakan lingkup hukum privat (hukum perdata), dibawa ke ranah pidana dengan menggunakan Pasal 378 Kitab UndangUndang Hukum Pidana (selanjutnya disingkat KUHP) tentang penipuan

${ }^{4}$ C.S.T. Kansil, Pengantar IImu Hukum. Jakarta : Balai Pustaka, 2002, h. 46

${ }^{5} /$ bid.
${ }^{6} /$ bid.
${ }^{7} /$ lbid.

${ }^{8}$ F.A.F Lamintang, Theo Lamintang,

Pembahassan KUHAP menurut IIImu

Pengetahuan Hukum Pidana dan Jurisprudensi, Jakarta: Sinar Grafika, 2010, h. 51. 
Media Komunikasi dan Informasi Hukum dan Masyarakat

sebagai penyelesaian dari masalah ingkar janji tersebut. Dalam praktik penegakan hukum berkenaan dengan kontrak, untuk segera mendapatkan haknya seseorang kerap mencari jalan pintas, salah satunya dengan cara melaporkan kepada pihak kepolisian (Perkara Pidana). Argumentasi sederhana yang dikemukakan, yaitu supaya pihak lawan "takut" akan pengenaan sanksi pidana, dan akhirnya tujuan untuk mendapatkan prestasi akan segera diperoleh.Terjadinya hal yang demikian itu menurut Yahman karena masyarakat tidak mengerti dan tidak memahami hukum, sehingga setiap permasalahan yang terjadi dilaporkan, apakah masalah yang dihadapi masuk kedalam lingkup hukum perdata atau hukum pidana, ia tetap melaporkan kepada pihak Polri dengan harapan cepat terselesaikan urusannya. $^{9}$

Kaidah hukum yang diambil dalam amar putusan Hakim dalam perkara tersebut adalah bahwa terdakwa terbukti melakukan tipu muslihat, rangkaian kata bohong sebelum menutup kontrak, kerja sama pemasangan AC tidak pernah terwujud. Unsur-unsur sengaja dalam delik penipuan telah terbukti.

Satu contoh kasus terbaru yang cukup menyita perhatian publik dan menuai pro dan kontra adalah kasus yang menjadi perhatian publik terkait masalah perjanjian yang dibawa ke jalur hukum pidana yaitu kasus First Travel. Ada argumentasi dari beberapa sarjana hukum bahwa kasus First Travel seharusnya diselesaikan melalui jalur perdata dengan mengajukan gugatan perdata, namun sebagian lagi menganggap jalan yang penyelesaian yang ditempuh sudah benar.

$$
\mathrm{Di} \text { Indonesia aturan mengenai }
$$
hubungan perseorangan tentang perikatan diatur dalam buku III Kitab Undang Undang Hukum Perdata (selanjutnya disingkat

${ }^{9}$ Yahman,Op.Cit. h. 4-6
KUHPerdata) tentang perikatan.Pasal 1233 KUHPerdata dinyatakan bahwa perikatan itu dapat lahir dari Undang-Undang dan Perjanjian.

Berbicara mengenai perjanjian, KUHPerdata dalam Pasal 1313 memberikan definisi mengenai perjanjian yang mengatakan :"Suatu perjanjian adalah suatu perbuatan dengan mana satu orang atau lebih mengikatkan dirinya terhadap satu orang lain atau lebih". Dalam melaksanakan suatu perjanjian, sering terjadi di antara para pihak yang telah melakukan perjanjian melakukan ingkar janji, tidak melaksanakan hak dan kewajiban yang telah disepakati antara kedua belah pihak,sehingga menimbulkan permasalahan hukum.

Dalam persepektif perlindungan hak asasi manusia (selanjutnya disebut HAM) dinyatakan bahwa kebebasan berkontrak merupakan HAM yang harus dihormati dan dilindungi. Pasal 11 International Convenant on Civil and Political Rights (ICCPR) lewat UndangUndang No. 12 tahun 2005 Tentang Pengesahan International Covenant on Civil and Political Rights (selanjutnya disebut UU pengesahan ICCPR), dinyatakan : "dan bahwa tidak seorang pun boleh dipenjarakan hanya atas dasar ketidakmampuannya memenuhi kewajiban kontraktualnya". Hal senada juga ditentukan di dalam Pasal 19 ayat (2) Undangundang Nomor 39 Tahun 1999 Tentang Hak Asasi Manusia (selanjutnya disebut UUHAM) yang mengatakan : "Tidak seorangpun atas putusan pengadilan boleh dipidana penjara atau kurungan berdasarkan atas alasan ketidakmampuan untuk memenuhi suatu kewajiban dalam perjanjian utang-piutang". Ketentuan norma dari kedua pasal tersebut dapat disimpulkan bahwa, seseorang tidak 
Media Komunikasi dan Informasi Hukum dan Masyarakat

dapat dihukum penjara karena tidak dapat memenuhi kewajiban perjanjiannya.

Hal inilah yang mendasari penulis bahwa perlu dilakukannya penelitian dalam hal menentukan antara perbuatan wanprestasi dan tindak pidana penipuan dari suatu perjanjian.

\section{B. Perumusan masalah}

Dari latar belakang di atas, dapat ditarik beberapa perumusan masalah yang antara lain:

1. Apa yang menjadi ciri-ciri normatif dari perbuatan Wanprestasi dan Tindak Pidana Penipuan?

2. Apa faktor penentu Wanprestasi dan Penipuan dari suatu perjanjian?

3. Bagaimana pertanggungjawaban perbuatan wanprestasi dan Tindak pidana Penipuan dari suatu perjanjian?

\section{Tujuan Penelitian}

Dari rumusan masalah di atas dapat dikemukakan tujuan penelitian ini adalah:

1. Mengetahui ciri-ciri normatif dari wanprestasi dan penipuan.

2. MenganalisisFaktor penentusuatu perjanjian sebagai perbuatan wanprestasi atau tindak pidana penipuan.

3. Menganalisis pertanggungjawaban wanprestasi dan tindak pidana penipuan dari suatu perjanjian.

\section{Manfaat Penelitian}

\section{a. Manfaat teoritis}

Secara teoritis, penelitian ini bermanfaat menambah pemahaman ilmu pengetahuan di bidang hukum, khususnya mengenai parameter penentu perbuatan wanprestasi dan tindak pidana penipuan dari suatu perjanjian.

\section{b. Manfaat praktis}

Secara praktis, penelitian ini bermanfaat sebagai bahan masukan bagi pihak pengambi keputusan / aparat penegak hukum penegak hukum. Khususnya yang berkaitan dengan penentu perbuatan wanprestasi dan penipuan

\section{E. Definisi Operasional}

Definisi Operasional didalam sebuah penelitian bertujuan untuk menghindari kesalahan pemahaman dalam menafsirkan istilah yang berkaitan dengan judul atau kajian penelitian. Untuk menjawab permasalahan dalam penelitian penelitian ini perlu didefinisikan beberapa konsep dasar dalam rangka menyamakan persepsi, yaitu sebagai berikut :

1. Perjanjian adalah kesepakatan antara satu pihak atau lebih untuk suatu objek atau kepentingan tertentu yang berorientasi pada materi atau dapat dinilai dengan uang.

2. Kontrak adalah perjanjian yang diakukan secara tertulis.

3. Wanprestasi adalah perbuatan ingkar janji yang merujuk pada perjanjian yang bisa dinilai dengan uang.

4. Penipuan adalah tindak pidana, yaitu rangkaian tipu muslihat sedemikian rupa yang dilakukan oleh seseorang untuk membujuk orang lain agar sepakat melakukan suatu hal sesuai dengan kehendak yang diinginkan dan memperoleh keuntungan dari perbuatan tersebut.

5. Parameter adalah tolak ukur atau ukuran, dalam penelitian penulisan penelitian iniadalah tolak ukur untuk menentukan wanprestasi dan penipuan. 
Media Komunikasi dan Informasi Hukum dan Masyarakat

\section{METODE PENELITIAN}

\section{A. Objek Penelitian}

Objek penelitian ini adalah norma hukum Pasal 1243 KUHPerdata tentang wanprestasi dan norma hukum Pasal 378 KUHP tentang tindak pidana penipuan.

\section{B. Sifat/Materi Penelitian}

Penelitian ini adalah penelitian normatif tentang kaedah hukum yang termuat pada Pasal 1243 KUHPerdata dan Pasal 378 KUHP. Sifat penelitian ini adalah penelitian deskriptif analisis yuridis. Dikatakan deskriptif karena dalam penelitian ini menggambarkan secara rinci dan utuh, sistematis dan menyeluruh tentang kaedah hukum yang termuat pada Pasal 1243 KUHPerdata dan Pasal 378 KUHP. Dikatakan analisis karena penelitian ini menguraikan secara lengkap, sistematis, menggunakan metode tertentu dan rinci tentang figur hukum dari norma hukum Pasal 1243 KUHPerdata dihubungkan dengan Pasal 378 KUHP. Dikatakan yuridis karena penelitian ini menggambarkan dan menganalisis penerapan norma hukum yang terkandung pada Pasal 1243 KUHPerdata dan Pasal 378 KUHP oleh pengadilan.

\section{Metode Pendekatan}

'Penelitian ini dilakukan melalui pendekatan yuridis normatif yaitu suatu penelitian yang secara deduktif menganalis norma hukum tertentu. Artinya analisis data dalam penelitian ini melalui pendekatan berdasarkan bahan hukum utama dengan cara menelaah teori-teori, konsep-konsep, asas-asas hukum serta peraturan perundang-undangan yang berhubungan dengan norma hukum Pasal 1243 KUHPerdata dan Pasal 378 KUHP.

\section{Data dan Teknik Pengumpulan Data}

1. Jenis data

Data yang dipergunakan dalam penelitian ini adalah data sekunder yang berupa literatur hukum, undang-undang, putusan pengadilan, makalah dan atau artikel yang termuat di media cetak maupun elektronik. Data sekunder yang dipergunakan dalam penelitian ini terdiri dari bahan hukum primer yang bersifat otoritatif yang artinya mempunyai otoritas, bahan hukum sekunder dan bahan hukum tertier.

Bahan hukum primer yang bersifat otoritatif yang dipergunakan dalam penelitian ini terdiri dari:

a. Undang-Undang Dasar Republik Indonesia Tahun 1945.

b. Kitab Undang-undang Hukum Pidana.

c. Kitab Undang-undang Hukum Perdata

d. Putusan Mahkamah Agung Republik Indonesia.

Bahan hukum sekunder yang dipergunakan dalam penelitian ini adalah doktrin hukum yang termuat di dalam buku literatur hukum perdata dan pidana, artikel dalam jurnal hukum, atau makalah yang ditulis para ahli yang materinya relevan dengan penelitian ini. Sedangkan bahan hukum tertier yang dipergunakan dalam penelitian ini adalah kamus hukum, ensiklopedia hukum dan kamus bahasa Indonesia.

\section{Sumber data}

Data sekunder untuk penelitian ini diperoleh melalui kepustakaan atau studi kepustakaan meliputi Buku-buku hukum, Undang-undang, Putusan Pengadilan, dan lain-lain baik yang termuat pada media cetak maupun media elektronik.

\section{E. Alat Pengumpulan Data}

Dalam upaya memperoleh data yang akurat, dalam penelitian ini data diperoleh 
Media Komunikasi dan Informasi Hukum dan Masyarakat

dengan menggunakan alat pengumpulan data menelaah dan menginventarisasi bahan-bahan hukum di kepustakaan (Library Research). Yaitu pengumpulan data dengan mengadakan studi telaah terhadap buku, literatur, Undang-Undang yang mempunyai korelasi dengan masalah yang diteliti yaitu mengenai parameter penentu pebuatan Wanprestasi dan Tindak Pidana Penipuan dari Satu Perjanjian.

\section{F. Analisis Data}

Analisis data dalam penelitian ini dilakukan analisis kualitatif.Data yang telah dihimpun dan diklasifikasi sesuai dengan permasalahan penelitian ini kemudian dilakukan analisis secara kualitatif (content analysis) dengan melakukan penafsiran atas data yang ada.

Penafsiran terhadap data yang dianalisis dapat menggunakan penafsiran otentik, gramatika maupun penafsiran teleologis khususnya terkait dengan sifat melawan hukum dari Pasal 1243 KUHPerdata dan Pasal 378 KUHP untuk dapat membedakan bentuk perbuatan wanpretasi dengan perbuatan pidana penipuan atas suatu perjanjian.

Hasil analisis kualitatif atau penafsirkan data kemudian diambil maknanya sehingga diketahui inti dari isi norma hukum yang diteliti dan dari makna tersebut digunakan untuk menjawab permasalahan yang ada sehingga diperoleh kesimpulan dari penelitian ini.

\section{PEMBAHASAN}

\section{A. Ciri-Ciri Normatif dari Wanprestasi dan Penipuan}

1. Ciri Normatif Wanprestasi

Manusia adalah makhluk yang paling sempurna di dunia ini. Kesempurnaan manusia dapat dipahami karena ia memiliki akal dan kehendak. Manusia dengan akalnya dapat melakukan penilaian, penjelasan dan pilihan. Oleh karenanya manusia, secara kodrati, memiliki hak fundamental yaitu kebebasan, hak hidup, dan keamanan pribadi.Dalam realitas kehidupan manusia, hakfundamental itu saling berinteraksi antaramanusia yang satu dengan manusia lainnya;salah satunya dalam wujud kontrak. ${ }^{10}$

ChantalMak menerangkan kontrak mengandung hak fundamental manusia dapat dilihat daridua kriteria:

Pertama, dilihat dari sisi formal; Kedua, dari sisi substansi. Secara formal suatuhak fundamental adalah hak yang ditentukandalam ketentuan konstitusi, sedangkan secarasubstansi hak adalah norma yang bertujuanuntuk menjamin martabat manusia atau hak yang mendasar bagi perlindungan otonomi pribadi. Kebebasan berkontrak adalah hak dasar seorang individu untuk masuk ke dalamperjanjian Itu memperoleh atau menyerahkan harta, jasa atau mengubah hubungan hukum. ${ }^{11}$

Pengaturan kontrak sebagai hak fundamental manusia dari sisi substansial di Indonesia dapat dilihat pada Pasal 1338 KUHPerdata yang di dalamnya terkandung asas kebebasan berkontrak. Secara umum pengaturan kontrak atau perjanjian dapat ditemui dalam KUHPerdata pada Buku III titel 2.

Perkataan "kontrak" dan "perjanjian" itu sama, dalam praktek-praktek sehari-hari mengartikan kontrak itu sebagai akta, tapi

${ }^{10}$ Zulfirman, "Kontrak sebagai sarana mewujudkan Kesejahteraan Sosial", Jurnal Rechtsvinding, Vol. 6, No 3, (Desember 2017), h. 405

11 Zulfirman, Hak Dasar Manusia Dalam Kontrak dan Perlindungannya di Indonesia, Intelegensia, Malang, 2017, h.274 
Media Komunikasi dan Informasi Hukum dan Masyarakat

sebenarnya kontrak itu perjanjian. ${ }^{12}$ Dalam hukum Islam, merujuk pada istilah yang berkaitan dengan perjanjian, agama Islam memiliki beberapa istilah sebagaimana Mashudi mengatakan:

Dalam Al-Qur'an, setidaknya ada 2 (dua) istilah yang berkaitan dengan perjanjian, yaitu kata akad (al-'aqdu) dan kata 'ahd (al-ahdu). Kata yang disebut pertama, secara etimologis berarti perjanjian, perikatan dan pemufakatan (al-ittifaq). Al-Qur'an memakai kata ini dalam arti perikatan dan perjanjian. Hal ini dapat dilihat dalam QS.AI-Maidah ayat (1). Sedangkan kata al-'Ahdu, secara etimologis berarti masa, pesan, penyempurnaan, dan janji atau perjanjian, hal ini dapat dilihat dalam AlQur'an surat An-Nahl ayat (91) dan AlIsra ayat (34). ${ }^{13}$

Kontrak / perjanjian sah apabila memenuhi syarat-syarat sahnya kontrak. syarat sah kontrak/perjanjian diatur dalam Pasal 1320 KUHPerdata, yaitu adanya kata sepakat mereka yang membuatnya, kecakapan untuk membuat suatu perikatan, suatu hal tertentu dan suatu sebab yang halal. Pengertian kata sepakat mereka yang mengikatkan dirinya yang dimaksud adalah izin kedua belah pihak berdasarkan persetujuan kehendak mereka masing-masing, artinya pada waktu kontrak itu diadakan tidak terdapat paksaan, penipuan, atau kekeliruan ${ }^{14}$.

Mengingat iktikad baik dalam kontrak merupakan doktrin atau asas yang berasal dari hukum Romawi, maka untuk mendapatkan pemahaman yang lebih baik harus dilacak ke dalam doktrin iktikad baik yang berkembang dalam hukum Romawi tersebut.

${ }^{12}$ H.Mashdui, et.al, Pengertian-Pengertian Elementer Hukum Perjanjian Perdata. CV. Mandar Maju, Bandung, 2001. h. 11

${ }^{13}$ Taryana. Op.Cit, h. 247

${ }^{14}$ Yahman.,Op.Cit. h. 72
Iktikad baik dalam hukum kontrak Romawi mengacu kepada tiga bentuk perilaku para pihak dalam kontrak.

Pertama, para pihak harus memegang teguh janji atau perkataannya. Kedua, para pihak tidak boleh mengambil keuntungan dengan tindakan yang menyesatkan terhadap salah satu pihak, Ketiga, para pihak mematuhi kewajibannya dan berperilaku sebagai orang terhormat dan jujur, walaupun kewajiban tersebut tidak secara tegas diperjanjikan. ${ }^{15}$

Di Indonesia, keharusan pelaksanaan iktikad baik dalam membuat suatu perjanjian tercantum dalam Pasal 1338 ayat (3) KUHPerdata yang menyatakan bahwa suatu perjanjian harus dilaksanakan dengan iktikad baik. Pasal ini menimbulkan pertanyaan apakah tidak diperlukan iktikad baik untuk membuat perjanjian (pra kontrak/perjanjian)?

\section{J.M.Van Dunne membagi tahapan} kontrak dalam tiga fase, yakni fase pra kontrak (precontractuale fase), fase pelaksanaan kontrak (contractuale fase) dan fase pasca kontrak (postcontractuale fase). Iktikad baik sudah harus ada sejak fase pra kontrak dimana para pihak mulai melakukan negosiasi hingga mencapai kesepakatan, dan fase pelaksanaan kontrak. ${ }^{16}$

Khairandy berpendapat bahwa ruang lingkup pengaturan iktikad baik dalam berbagai sistem hukum umumnya hanya mencakup iktikad baik dalam fase pelaksanaan kontrak, belum mencakup fase pra kontrak ${ }^{17}$. Mengacu pada pendapat Agung Sujatmiko mengutip Yohanes Sogar Simamora yang menerangkan kriteria perilaku iktikad baik dalam pelaksanaan perjanjian pengujiannya didasarkan pada norma-norma objektif yang tidak

\footnotetext{
${ }^{15}$ /bid, h. 132

${ }^{16}$ Ibid, h 190

${ }^{17}$ Ridwan Khairandy, Ibid, h 191
} 
Media Komunikasi dan Informasi Hukum dan Masyarakat

tertulis ${ }^{18}$.Zulfirman berpendapat iktikad baik berlaku pada fase pra kontrak, sebagaimana dikatakannya:

Paksaan, tipuan, dan kekeliruan adalah parameter normatif terkait iktikad baik seseorang yang akan membangun perjanjian; kesemuanya berkaitan dengan ketidakpatutan, ketidakjujuran dan ketidakadilan dalam membuat perjanjian. Paksaan, tipuan dan kekeliruan diambil alih dari normanorma objektif yang tidak tertulis yang berkembang di dalam masyarakat diformalkan menjadi norma hukum tertulis. Itulah sebabnya mengapa Pasal 1338 KUHPerdata tidak lagi ditentukan iktikad baik sebagai dasar membuat perjanjian. ${ }^{19}$

Selain iktikad baik dalam perjanjian juga berlaku prinsip mengikatnya suatu perjanjian yang telah dibuat secara sah oleh masingmasing pihak. Perjanjian yang sudah dibuat tidak dapat ditarik secara sepihak kecuali atas kesepakatan kedua belah pihak. Hal ini tercantum dalam Pasal 1338 ayat (2) KUHPerdata yang merupakan kelanjutan dari Pasa 1338 ayat (1) KUHPerdata.

Suatu perjanjian akan melahirkan kewajiban yang bersifat positif dan negatif. Kewajiban yang bersifat positif (positive duties) pada dasarnya merupakan kewajiban untuk melakukan sesuatu (duty to do), sedangkan yang bersifat negatif (negative duties) merupakan suatu kewajiban untuk mematuhi larangan (duty not to do ${ }^{20}$. Kewajiban yang lahir dari suatu perjanjian disebut prestasi. Jadi, prestasi adalah suatu yang wajib harus dipenuhi oleh debitor dalam setiap perikatan. ${ }^{21}$

${ }^{18}$ Moch.Isnaeni, Perkembangan Hukum Perdata di Indonesia, Laksbang Grafika, Yogyakarta, 2013. h 189

${ }^{19}$ Zulfirman, Hak Dasar Manusia Dalam Kontrak dan Perlindungannya di Indonesia, Intelegensi Media, Malang, 2017. h. 235

${ }^{20}$ Ibid, h. 79

${ }^{21}$ Riduan Syahrani, Seluk Beluk dan Asas-Asas Hukum Perdata, Bandung, 1992, h. 228
Prinsip yang terkandung dalam hubungan kontraktual yaitu adanya jaminan kepastian pelaksanaan kontrak. Apabila tidak adanya suatu keseimbangan pelaksanaan hak dan kewajiban dalam hubungan kontraktual, maka akan timbul pelanggaran kepentingan atau hak salah satu pihak, jika hal ini terjadi maka timbul suatu peristiwa hukum yang dinamakan "wanprestasi". ${ }^{22}$

Wanprestasi harus didasari adanya suatu perjanjian, baik perjanjian tersebut dibuat secara lisan maupun tertulis, baik dalam bentuk perjanjian dibawah tangan maupun dalam akta autentik. Seseorang tidak dapat dinyatakan wanprestasi, jika ia tidak terikat dalam suatu hubungan kontraktual ${ }^{23}$.

\section{B. Faktor Penentu suatu Perjanjian sebagai Perbuatan Wanprestasi atau Tindak Pidana Penipuan.}

Pada pembahasan di atas telah disinggung bahwa perjanjian merupakan bagian dari lapangan hukum privat, karena ikatan yang lahir dari perjanjian hanya berlaku mengikat bagi masing-masing pihak yang mengikatkan diri dalam perjanjian tersebut.

Namun pada praktiknya, ketika muncul masalah yang timbul dari perjanjian, tidak jarang dalam penyelesaiannya perjanjian yang pada dasarnya merupakan lingkup hukum privat (hukum perdata), dibawa ke ranah pidana dengan menggunakan Pasal 338 KUHP tentang penipuan sebagai penyelesaian dari masalah yang muncul dari perjanjian tersebut.

Dalam praktik penegakan hukum berkenaan dengan kontrak, untuk segera mendapatkan haknya seseorang kerap mencari jalan pintas, salah satunya dengan cara

\footnotetext{
${ }^{22}$ Yahman, Loc.Cit

${ }^{23}$ Ibid, h. 24
} 
Media Komunikasi dan Informasi Hukum dan Masyarakat

melaporkan kepada pihak kepolisian (Perkara

Pidana). Argumentasi sederhana yang dikemukakan, yaitu supaya pihak lawan "takut" akan pengenaan sanksi pidana, dan akhirnya tujuan untuk mendapatkan prestasi akan segera diperoleh.

Implementasi kepastian hukum yang tidak tercermin dengan baik dalam praktik yang berkaitan dengan masalah perjanjian, maka perlu kiranya diteliti parameter penentu perbuatan wanprestasi dan penipuan agar tercapai kepastian hukum bagi masing-masing pihak yang melakukan perjanjian.

Berdasarkan uraian ciri normatif wanprestasi dan penipuan yang telah analisis pada sub bab di atas, maka dapat dicermati antara wanprestasi dan penipuan mempunyai ciri normayang berbeda satu sama lainya, dari perbedaan ciri normatif tersebut dapat dianalisis parameter untuk menentukan bedawanprestasi dengan penipuan.

Dengan berpegang pada hasil analisis pada sub-bab di atas dan masing-masing sub bab tersebut dikomparasikan, maka dapat dikemukakan parameter penentu antara wanprestasi dan penipuan dapat adalah sebagai berikut :

1. Wanprestasi berhubungan erat dengan perjanjian sebagai hubungan hukum antar individu. Perjanjian itu sendiri dilahir atas kesepakatan sebagai mana dimaksud pada Pasal 1320 KUHPerdatayang mengandung pengertian para pihak saling menyatakan kehendak masing-masing untuk membuat suatu kehendak ; pernyataan satu pihak sudah disetujui oleh pihak lain ${ }^{24}$. Tegasnya perbuatan wanprestasi adalah pelanggaran atas hukum yang mereka lahirkan sendiri. Di sini isi subjek normanya indibidu dengan individu. Sedangkan penipuan adalah ketentuan undang-undang yang mengatur tentang kejahatan terhadap harta. Jadi parameter menentukan wanprestasi adalah pelanggaran terhadap janji atau hukum yang dibuat oleh para pihak dalam hubungan individu. Di sini subjek normanya negara berhadapan dengan individu.

Parameter menentukan suatu tindak pidana penipuan adalah perbuatan kejahatan (mens rea) terhadap harta kekayaan seseorang, yang dilakukan dengan cara culas atau melalui kebohongan sehingga seseorang menyerahkan barang atau benda tidak atas dasar kesukarelaan. Pidana penipuan yang diatur di dalam KUHP karakter hukumnya berbeda dengan penipuan sebagai syarat sahnya perjanjian. Penipuan di sini ditujukan kepada kesepakatan sebagai syarat sahnya perjanjian bukan ditujukan kepada harta kekayaan sebagaimana ditentukan dalam penipuan dalam KUHP. Jelasnya, penipuan terkait dengan syarat sahnya perjanjian, kesepakatan yang ditutup dalam suatu perjanjian memberi cacat pada kehendak, sebab salah satu pihak memberikan kesesatan terhadap pihak lain dalam memberikan gambaran perjanjian. sehingga dalam penipuan kedudukan antara pihak satu dengan yang lainnya tidak seimbang.

2. Wanprestasi merupakan tindakan melanggar kewajiban pribadi yang muncul dari hubungan hukum yang dibuat oleh para pihak melalui suatu perjanjian. Sedangkan penipuan adalah perbuatan yang dilakukan secara melawan hukum terhadap harta kekayaan seseorang.

${ }^{24}$ Yahman., Op.Cit, h. 56 
Media Komunikasi dan Informasi Hukum dan Masyarakat

Dengan dicantumkannya ketentuan seperti termuat dalam Pasal 1 ayat (1) KUHP, maka barang siapa yang terbukti telah melanggar suatu ketentuan pidana, secara formal perbuatan dimaksud adalah melawan hukum karena perbuatan termaksud telah melanggar suatu larangan yang dicantumkan dalam Undang-Undang Pidana $^{25}$. Sedangkan Hamel yang dikutip oleh R.Achmad S. Soema berpendapat sifat melawan hukum dari suatu delik merupakan salah satu bagian dari pengertian umum dari tindak pidana sehingga menurut pendapatnya, dalam hal dimaksud itu tida dimuat dalam rumusan delik, bagian tersebut dianggap selalu $\mathrm{ada}^{26}$.

Lewat pengertian di atas, dapat dicermati "secara melawan hukum" yang dimaksud dalam Pasal 378 KUHP secara konkrit ditandai dengan memakai nama palsu atau martabat palsu, dengan tipu muslihat, ataupun rangkaian kebohongan , menggerakkan orang lain untuk menyerahkan barang sesuatu kepadanya, atau supaya memberi utang maupun menghapuskan piutang.

3. Wanprestasi dilatarbelakangi oleh prinsip iktikad baik. Artinya debitor memiliki upaya untuk memenuhi prestasi sesuai apa yang diperjanjikan walaupun dalam pelaksanaannya berakhir pada prestasi buruk. Pasal 1338 point ke 3 yang menyatakan :"Suatu perjanjian harus dilaksanakan dengan iktikad baik."Sedangkan pada penipuan, dilatarbelakangi perbuatan jahat (mensrea) hal ini dapat dilihat dari unsur subjektif tindak pidana penipuan,yaitu : dengan maksud menguntungkan diri sendiri atau orang lain terdapat unsur kesengajaan (dolus/opzet), tidak dalam bentuk ketidaksengajaan.

${ }^{25}$ R.Achmad S.Soema di Pradja. Pengertian serta sifatnya melawan hukum bagi terjadinya tindak pidana, Armico, Bandung. 1983, h. 23

${ }_{26}$ /bid, h. 27

\section{Bentuk Pertanggungjawaban Wanprestasi} dan Penipuan.

Hukum secara garis besar dibuat untuk mengatur kehidupan yang ada di masyarakat. Kansilmengutip pendapat J.C.T.Simorangkir dan Woerjono Sastropranoto yang menyatakan bahwa hukum adalah peraturan-peraturan yang bersifat memaksa, yang menentukan tingkah laku manusia dalam lingkungan masyarakat yang dibuat oleh badan-badan resmi yang berwajib. Pelanggaran mana terhadap peraturan-peraturan tadi berakibatkan diambilnya tindakan, yaitu dengan hukuman tertentu. ${ }^{27}$ Dapat diambil kesimpulan dari definisi di atas, bahwa pertanggungjawaban dalam bentuk sanksi dibebankan kepada siapa saja yang melanggar perbuatan yang telah ada pengaturannya.

Suatu perbuatan dikatakan sebagai perbuatan hukum apabila perbuatan tersebut mempunyai akibat hukum. Oleh karenanya, suatu perbuatan hukum mempunyai konsekuensi pertanggungjawaban hukum. Berbicara persoalan pertanggungjawaban terkait pembahasan tulisan ini, maka wanprestasi dan penipuan termasuk perbuatan yang telah diatur dalam peraturan perundangundangan, yang apabila dilanggar keduanya memiliki sanksi bagi pelanggarnya.

Sanksi terhadap suatu peristiwa hukum yang dilakukan oleh seseorang digantungkan dari jenis perbuatan hukumnya dan bidang hukum yang mengaturnya. Penulisan ini akan membatasi analisis terkait dengan sanksi di bidang hukum perdata khususnya mengenai wanprestasi dan sanksi tindak pidana penipuan.

${ }^{27}$ C.ST.Kansil, Pengantar IImu Hukum, Balai Pustaka, Jakarta, 2002, h. 8 
Media Komunikasi dan Informasi Hukum dan Masyarakat

Pelanggaran terhadap suatu peristiwa

pidana dapat dijatuhkan hukuman sesuai dengan bentuk kesalahan dari pelakunya. Jenis sanksi terhadap pelanggaran suatu peristiwa pidana ditentukan di dalam Pasal 10 KUHP yaitu :

1. Pidana Pokok
a. Pidana mati;
b. Pidana penjara;
c. Pidana kurungan;
d. Pidana denda;
e. Pidana tutupan.

2. Hukum Pidana Tambahan
a. Pencabutan hak-hak tertentu;
b. Perampasan barang-barang tertentu;
c. Pengumunan putusan hakim.

Oleh karena penipuan berbeda dengan wanprestasi, di mana masing-masing perbuatan yang berasal dari lapangan hukum yang berbeda, maka sudah tentu pula bentuk pertanggungjawabannya juga berbeda. Bentuk pertanggungjawaban dari wanprestasi sebagai dan penipuan, akan lebih baik jika terlebih dahulu dibahas mengenai bagian dari hukum perdata, untuk melihat bentuk pertanggungjawabannya dapat dilihat dari putusan hakim. Adapun sanksi dalam hukum perdata dapat dilihat dari jenis putusan hakim yang membedakan putusan dalam 3 jenis, yaitu:

1. Putusan condemnatoir, yaitu putusan yang bersifat menghukum. Hukuman dalam perkara perdata berlainan dengan hukuman dalam perkara pidana. Dalam perkara perdata, hukuman artinya kewajiban untuk memenuhi prestasi yang dibebankan oleh hakim ${ }^{28}$. Prestasi itu dapat berwujud memberi (geven, give), berbuat sesuatu

${ }^{28}$ Abdulkadir Muhammad, Hukum Acara Perdata Indonesia, Alumni, Bandung, 1978, h. 167 (doen, do), atau tidak berbuat sesuatu (niet doen, not do).

2. Putusan declatoir, adalah putusan yang bersifat menyatakan hukum, atu menegaskan suatu keadaan hukum hukum tertentu yang dimohonkan itu ada atau tidak ada. ${ }^{29}$ Putusan declatoir bersifat penetapan saja tentang keadaan hukum, tidak bersifat mengadili, karena tidak ada sengketa. ${ }^{30}$

3. Putusan constituef

Putusan constitutief adalah putusan yang bersifat menghentikan atau menimbulkan keadaan hukum baru. Dalam putusan ini suatu keadaan hukum tertentu dihentikan atau ditimbulkan suatu keadaan hukum baru. ${ }^{31}$ Misalnya, putusan pembatalan perkawinan.

Dari uraian di atas dapat disimpulkan bahwa sanksi dalam hukum perdata adalah :

a. Kewajiban untuk memenuhi prestasi

b. Ganti kerugian

c. Hilangnya suatu keadaan hukum, yang diikuti dengan terciptanya suatu keadaan hukum yang baru.

Bentuk pertanggungjawaban dari pelaku wanprestasi biasanya diberikan oleh hakim berdasarkan apa yang dituntut pihak kreditor. Pihak kreditor biasanya mengajukan gugatan yang pada petitumnya mengikuti ketentuan Pasal Pasal 1239 KUHPerdata yang menyatakan bahwa : "Tiap-tiap perikatan untuk berbuat sesuatu, atau tidak berbuat sesuatu, apabila si berutang tidak memenuhi kewajibannya, mendapatkan penyelesaiannya dalam kewajiban memberikan penggantian biaya, rugi dan bunga." Selain itu juga dipakai Pasal 1243 KUHPerdata sebagai dasar 
Media Komunikasi dan Informasi Hukum dan Masyarakat

meminta bentuk pertanggungaban pelaku wanprestasi berupa penggantian biaya, rugi dan bunga diwajibkan kepada si berutang karena tidak terpenuhinya suatu perikatan. Artinya, dalam perkara ingkar janji atau wanprestasi menjadi mutlak bentuk pertanggungjawabannya dengan pemenuhan prestasi atau ganti kerugian biasanya dalam bentuk pembayaran kekayaan atau melakukan suatu perbuatan tertentu.

Pertanggung jawaban pelaku wanprestasi sebatas melakukan sesuatu atau membayar sesuatu dengan kekayaan atau sesuatu yang dapat dinilai dengan uang, tidak dapat dimintai pertanggungjawaban dalam bentuk merampas kebebasan dari pelaku wanprestasi. Hal initegas dinyatakan dalam UU pengesahanICCPR dalam Pasal 11 dinyatakanbahwa tidak seorangpun boleh dipenjarakan hanya atas dasar ketidakmampuannya memenuhi kewajiban kontraktualnya.

Ketentuan Pasal 11 UU pengesahan ICCPR tersebut, senada dengan Pasal 19 ayat (2) UUHAM yang mengatakan : "Tidak seorangpun atas putusan pengadilan boleh dipidana penjara atau kurungan berdasarkan atas alasan ketidakmampuan untuk memenuhi suatu kewajiban dalam perjanjian utangpiutang".

Oleh sebab itu jelaslah bahwasanya setiap prestasi yang tidak terpenuhi dalam suatu perjanjian, tidak dapat dipidana karenanya. Melainkan dengan cara ganti kerugian sesuai dengan bentuk pertanggungjawaban yang ada di dalam Hukum Perdata.

Pertanggungjawaban wanprestasi dan penipuan mempunyai koridornya masingmasing sehingga dapat dibedakan dengan jelas bentuk pertanggungjawabannya.Pemahaman karakteristik antara wanprestasi dan penipuan sangat penting untuk diketahui terutama oleh para penegak hukum di Indonesia agar tercapainya kepastian hukum. Sebab, apabila kurangnya pemahaman karakteristik antara wanprestasi dan penipuan, disamping tidak tercapainya tujuan hukum, hal ini juga menyangkut hak asasi manusia. Seseorang akan terenggut kebebasannya jika para penegak hukum salah dalam mengambil keputusannya.

Mengutip satu adagium hukum terkenal yang selaras dengan dengan karya ilmiah ini :

"Lebih baik membebaskan 1000 orang yang bersalah daripada menghukum satu orang yang tidak bersalah".

\section{KESIMPULAN DAN SARAN}

\section{A. Kesimpulan}

1. Bahwa, wanprestasi adalah perbuatan ingkar janji atau tidak memenuhinya suatu prestasi dan merupakan bagian dari lingkungan hukum perdata. Sedangkan penipuan merupakan perbuatan dalam lingkungan hukum pidana, dimana perbuatan curang dilakukan dengan maksud memperoleh keuntungan secara sepihak.

2. Faktor penentu antara wanprestasi dan penipuan adalah:

a. Wanprestasi timbul akibat perjanjian yang dibuat secara sah. Sedangkan dalam penipuan, kesepakatan yang ditutup dalam suatu kontrak/perjanjian yang disepakati mengalami cacat kehendak.

b. Wanprestasi merupakan tindakan melawan perikatan. Sedangkan 
Media Komunikasi dan Informasi Hukum dan Masyarakat

penipuan adalah perbuatan yang dilakukan secara melawan hukum.

c. Wanprestasi dilatarbelakangi oleh prinsip iktikad baik.. Sedangkan pada penipuan, tidak ada upaya iktikad baik yang dilakukan.

3. Bentuk pertanggungjawaban Wanprestasi dan Penipuan adalah:

Wanprestasi merupakan bagian dari hukum perdata, dimana bentuk pertanggungjawabannya adalah berupa ganti kerugian, Sedangkan dalam penipuan, sesuai dengan karakteristik sanksi dalam pidana, bentuk pertanggungjawaban yang dikenakan berupa hukuman penjara.

\section{B. Saran}

1. Advokat atau kuasa hukum sebagai pendamping klien atau pihak-pihak awam yang bersengketa dalam hal perjanjian, diharapkan tidak gegabah dengan mengutamakan jalur pidana dalam penyelesaian perkara yang berkaitan dengan perjanjian tanpa melihat duduk perkara secara substansial.

2. Hakim dalam menjatuhkan hukuman yang berkaitan dengan masalah perjanjian, ada baiknya melihat terlebih dahulu perbuatan yang dilakukan secara substansial khususnya pada mengenai wanprestasi dan penipuan.

3. Setiap orang yang ingin melakukan perjanjian, ada baiknya terlebih dahulu mengetahui konsep dasar perjanjian secara hukum, agar tidak terjadi kerancuan dalam membedakan wanprestasi dan penipuan.

\section{Daftar Bacaan}

A.Buku

Abdulkadir Muhammad, Hukum Acara Perdata Indonesia, Alumni, Bandung, 1978.

Achmad Ihsan, Hukum Perdata PT.Pembimbing Masa, Jakarta, 1967,

Adami Chazawi. Kejahatan terhadap harta benda. Media nusantara creative, Malang. 2004.

Agus Yudha Hernoko, Asas Proporsionalitas Dalam Kontrak Komersial, Laksbag Mediatama, Yogyakarta, 2008

Bambang Poernomo, Asas-Asas Hukum Pidana, Ghalia Indonesia, Yogyakarta, 1985.

C.ST.Kansil, Pengantar IImu Hukum, Balai Pustaka, Jakarta, 2002.

F.A.F Lamintang, Theo Lamintang, Pembahasan KUHAP menurut IImu Pengetahuan Hukum Pidana dan Jurisprudensi, Jakarta: Sinar Grafika, 2010

H.Mashdui, et.all, Pengertian-Pengertian Elementer Hukum Perjanjian Perdata.CV. Mandar Maju, Bandung, 2001.

Hardijan Rusli. Hukum Perjanjian Indonesia dan Common Law. Pustaka Sinar Harapan, Jakarta, 1993.

Komariah Emong Sapardjaja, Ajaran Sifat

Melawan Hukum Materil Dalam Hukum Pidana Indonesia, Alumni, Bandung, 2002.

M.Yahya Harahap, Segi-Segi Hukum Perjanjian, Alumni, Bandung, 1986,

Mariam Darus Badrulzaman, Asas-Asas

Hukum Perikatan, FH USU, Medan, 1970

Nindyo Pramono, Hukum Komersil, Pusat Penerbitan UT, Jakarta; 2003, 
Media Komunikasi dan Informasi Hukum dan Masyarakat

P.A.F.Lamintang, Dasar-Dasar Hukum Pidana

Indonesia, Citra Aditya Bakti, Bandung, 1997.

R.Achmad S.Soema di Pradja. Pengertian serta sifatnya melawan hukum bagi terjadinya tindak pidana, Armico, Bandung. 1983.

R.Setiawan, Pokok-Pokok Hukum Perjanjian,

Putra Abadin, Jakarta, 1999,

R.Soesilo, Kitab Undang- Undang Hukum

Pidana serta Komentar-Komentarnya lengkap dengan Pasal demi Pasal, PT.Gita Karya, Jakarta, 1976.

Ridwan Khairandy, Iktikad Baik dalam Kebebasan Berkontrak, Universitas Indonesia, Fakultas Hukum, Pascasarjana, Jakarta, 2003

Ridwan Syahrani, Seluk Beluk dan Asas-Asas

Hukum Perdata , Bandung, 1992.

Satochid-Kartanegara, Kumpulan Kuliah

Hukum Pidana dan Pendapatpendapat para Ahli Hukum

Terkemuka Bagian satu, Balai Lektur

Mahasiswa, Jakarta,

Soedjono Dirdjosisworo, Misteri dibalik

Kontrak Bermasalah, Mandar Maju, Bandung, 2002,

Subekti, Hukum Perjanjian, Intermasa, Jakarta, 2005

Subekti, Pokok-Pokok Hukum Perdata, PT Intermasa, Jakarta, 1980,

Taryana Soenandar, et.all Kompilasi Hukum

Perikatan PT.Citra Aditya Bakti, Bandung 2016. hlm 65

Wiryono Prodjodikoro, Tindak Pidana Tertentu di Indonesia, Eresco DjakartaBandung, 1967.

Yahman, Karakteristik Wanprestasi \& Tindak Pidana Penipuan yang lahir dari
Hubungan

Kontraktual,

Prenadamedia Group, Jakarta 2014,

Zulfirman, Hak Dasar Manusia Dalam Kontrak dan Perlindungannya di Indonesia, Intelegensia, Malang, 2017.

\section{B.Jurnal}

Zulfirman, Kontrak sebagai sarana mewujudkan Kesejahteraan Sosial, Jurnal Rechtsvinding, Vol. 6, No 3, (Desember 2017).

Zulfirman, Hak Dasar Manusia Dalam Hukum Kontrak Indonesia: Analisis Kritis Syarat Kontrak, Jurnal De Jure, Vol. 7, Nomor 2, Juni 2017

\section{C.Kamus}

Departemen Pendidikan dan Kebudayaan, Kamus Besar Bahasa Indonesia, Jakarta 1988

\section{C.Undang-Undang}

Kitab Undang-Undang Hukum Perdata

Kitab Undang-Undang Hukum Pidana

Undang-Undang No.12 Tahun 2005 tentang pengesahan International Convenant Civil and Political Right.

Undang-Undang No.39 Tahun 1999 tentang Hak Asasi Manusia

\section{D.Putusan Pengadilan}

Putusan Mahkamah Agung RI No.

449K/Pid/2001

Putusan Mahkamah Agung RI No.2674

$\mathrm{K} / \mathrm{Pid} / 2006$

Putusan Tingkat Pertama Pengadilan Negeri Jakarta Pusat dalam putusan Nomor : 1782/Pid.B/2004/PN.JKT PST 